\title{
Retratar, retratar-se, ser retratado
}

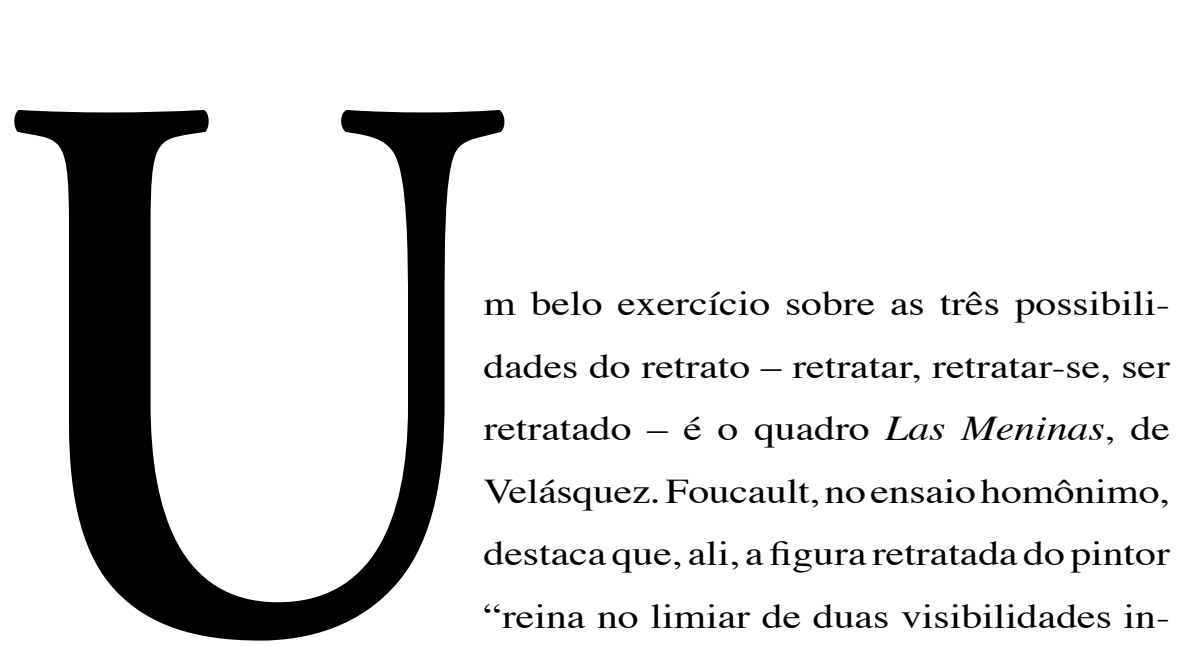

TERESA CRISTÓFANI

BARRETO é professora do Departamento de Letras Modernas da FFLCH-USP e autora de, entre outros, Calentura (lluminuras).

compatíveis" ". Pois reza a norma que ou o pintor é visto no quadro que o representa (o auto-retrato) ou vê o quadro que pinta. Ali, ele pinta, vê o que pinta e é visto pintado. Ou, quem sabe, pintando-se a si mesmo. Ao mesmo tempo, ele nos olha nos olhos, o que "nos atinge infalivelmente e nos liga à representação do quadro"². Porque, em geral, ser observado por um pintor que tem, diante de si, uma tela e, numa das mãos, o pincel é ter um destino: o de ser imobilizado no quadro, o de ter uma imagem só vista naquele momento pelo artista, plasmada para sempre naquela superfície.

Aquela tela desdobra-se, portanto, em duas: numa que contém e noutra que é contida. Em seu limiar, posta-se o pintor, retratando-nos. E retratado por si próprio.

Michel Foucault, "As Meninas" in As Palavras e as Coisas, trad. de Salma Tannus Muchail São Paulo, Martins Fontes, 1985, p. 20

2 Idem, ibidem 
O que mais nos inquieta, no entanto, é a certeza de estarmos sendo tragados para dentro da tela contida no suporte maior, onde se estabelece o pacto ficcional. Durante o tempo em que miramos a tela, nos embrenhamos em sua entranha e ficamos à mercê da representação, tanto quanto o próprio pintor. E fitar o avesso da tela, descobrir sua estrutura de madeira, onde se fixa o tecido - sua composição concreta, comezinha, sempre ocultada -, ao mesmo tempo em que somos fitados pelo pintor, é uma revelação. É saber-nos posando para um pintor famoso. (Note-se que o gerúndio é a forma nominal dos verbos - outra compatibilização de dois limiares - que mais se presta para esta verificação.) Afinal, “somos vistos ou vemos?", indaga Foucault sobre a relação entre nós, espectadores, e o pintor espanhol.

Mas a recíproca é verdadeira. O pintor contraria todas as convenções e se deixa flagrar ao lado do cavalete, revelando o reverso de seu quadro. A propósito, quando se trata de um registro do pintor e sua obra, uma imperiosa convenção se impõe, até aos mais desabusados, os mais vanguardistas, os amantes das novidades. Mesmo depois do advento da fotografia, os pintores são sempre retratados ou ao lado ou diante de alguma tela de sua autoria. Fazem lembrar o caçador que ostenta a presa empalhada, seu troféu. Ou o pescador que prova sua proeza ao lado da balança de onde pende o peixão. Etc. Pergunto-me então: onde estariam escondidas as fotos brincalhonas que os tomariam de frente para o fotógrafo, e diante da tela, de modo que desta só fosse possível vero avesso, tal como o quadro que Velásquez pinta no presente de Las Meninas? Nem Man Ray fugiu da convenção de se fotografar diante das próprias telas, com ou sem a presença viva de seus modelos.

A implicação mais direta dessa ausência é um impossível. Quem jamais posou para um pintor jamais terá tido a oportunidade de conhecer aquela ordenação cenográfica - ainda que ficcional - entre o pintor, seu olhar direto e o reverso da tela - cavalete, estrutura de madeira e o avesso do tecido.

O contrário também resulta verdadeiro. Raras são as fotos de pintores em plenoexer- cício, de costas para o fotógrafo, em total imersão no trabalho, apesar do flagrante. Só quem compartilhou dessa intimidade, no ateliê do artista, conhece-lhe o avesso enquanto pinta. Mesmo para estes, uma foto que revele o pintor de costas ao espectador, preocupado tão-somente com seu ofício, provoca alguma estranheza.

Faço essas considerações iniciais para refletir sobre as relações entre aquele que retrata, o retrato e o retratado num caso bem mais próximo, no tempo e no espaço. Mas que igualmente guarda algumas narrativas outras, que excedem o âmbito do que é manifesto. Nestas épocas pródigas em desentranhar milionárias mensagens cifradas em obras de arte - em afrescos, por que calá-lo? -, acabei eu mesma adivinhando um eventual sistema deixado pelo artista. Refiro-me a uma das mais importantes realizações do pintor Samson Flexor, os afrescos da igreja Nossa Senhora do Perpétuo Socorro, no Jardim Paulistano, em São Paulo, que, paradoxalmente, têm recebido interesse menor diante do conjunto de sua obra. Uma folheada na recente reedição, revista, da obra Flexor ${ }^{3}$, de Alice Brill, corrobora minha afirmação ${ }^{4}$.

\section{FLEXOR RETRATA, RETRATA-SE, É RETRATADO}

O próprio Flexor, sujeito definido, conjugou o verbo retratar em suas três possibilidades - voz ativa, reflexiva e passiva - em sua criação dos afrescos da Perpétuo Socorro.

Composto de seis grandes blocos, o trabalho distribui-se pela entrada, onde, à esquerda, localiza-se o batistério; pela extensão lateral esquerda, por onde um dilatado grupo de fiéis - a Igreja Militante - se perfila; pela lateral direita, onde, na mesma extensão, sucedem-se os santos, que formam a Igreja Triunfante; pela cena do milagre da santa, ocorrido nas Filipinas, em frente à Igreja Padecente, em ambas as laterais do altar; e, finalmente, pelo altar- 
mor, em cuja cúpula reina a Nossa Senhora, ladeada pelos quatro evangelistas.

De todo o conjunto, interessa-me recortar a extensão lateral esquerda. Conforme o próprio artista,

“O tema da 'Igreja Militante' continua [...] na nave principal (lado do Evangelho) num friso de 24 metros de comprimento evocando a 'Humanidade Sofredora à Procura de Auxílio'. Um jogo rítmico de diagonais compõe uma estrutura dinâmica orientando o movimento dos personagens dirigindo-se na direção do 'Quadro'5 da Abside.

As personagens medem cerca de 2,25 metros de altura, sendo os espaços mais altos entre as janelas ocupados por grandes figuras de anjos de 3 metros que guiam essa multidão sofredora indicando-lhe o caminho da salvação e do auxílio. A velhice, a miséria, a enfermidade e a guerra estão personificadas pelas figuras masculinas, femininas e infantis. Os pontos culminantes deste desfile são a Morte de um filho e a Ciência que procura salvá-lo. Essas duas estações são sublinhadas por dois anjos, o primeiro, sustentando o caixão com o filho morto, e o segundo, segurando um conjunto de instrumentos científicos do biólogo (um cientista cristão êmulo de Pasteur).

As personagens que seguem representam várias atividades intelectuais e artísticas, também necessitadas do auxílio divino, e o clero representado na vanguarda do desfile pelos bispos e padres tendo à frente (extremidade avançada do friso) um grupo de coroinhas que personificam a inocência agradável a Deus.

As cores predominantes desta composição extensa são os azuis esverdeados, que significam as águas do batismo, cinzas da contrição, roxos e pretos que nos falam do luto e da morte"

O referido "jogo rítmico de diagonais [que] compõe uma estrutura dinâmica" marca o estilo do pintor que, naqueles anos, ainda operava com tais movimentos, que pesquisava no Ateliê Abstração. Uma de suas alunas, Leyla Perrone-Moisés, assim descreve seu programa:
"Flexor colocou sobre uma mesa alguns objetos - um violão, um vaso, uma bandeja - e pediu-me não que os copiasse, mas que observasse a relação entre as formas e as dimensões e procurasse as linhas ocultas que podiam ligar esses objetos uns aos outros e às margens do papel. [...] As linhas que eu ia traçando criavam, no interior dos objetos representados, numerosas formas menores, que eu devia 'colorir' apenas com traços paralelos ou cruzados, mais claros ou mais escuros, sem preocupação com as sombras da realidade, apenas com a composição total que se ia formando. A essas diferentes intensidades de claro e escuro, Flexor chamava 'valores', e mais tarde vim a compreender sua importância. [...]

[...] eu aprendera algumas coisas com o mestre: o gosto do trabalho paciente e bem executado; a repulsa pelas misturas 'sujas', frutos do acaso e do descaso; a recusa dos 'valores' mal definidos que, quando vizinhos, criavam efeitos desagradáveis ao olhar; a tendência a prolongar as linhas mestras, sem deixar pontas soltas. O que eu estava aprendendo era a tramar aquela teia geométrica que, aparente ou não, sustentava os quadros do mestre""7.

Os afrescos, conforme o método de trabalho descrito, consistem numa extensa exposição de personagens que se orientam em direção ao grande centro, representado pela figura maior de Nossa Senhora do Perpétuo Socorro, determinados e dirigidos graças ao dinamismo das formas e das linhas diagonais. Descobrem-se, portanto, não apenas as figuras humanas, mas os traços que as constroem. Assim, paralelo à descrição dessa "Humanidade Sofredora à Procura de Auxílio", assiste-se à sua construção, já que as linhas mestras que a compõem são visíveis, concretas. Sua sintaxe é explícita: cria-se quase um efeito narrativo para sua concepção e edificação. Segundo René Deroudille,

"Fiel às regras de ouro do construtivismo, Samson Flexor obedece aos ritmos rigorosos da horizontal-vertical, em obras dedicadas ao quadrado, ao cubo e à poesia do ângulo
5 Nossa Senhora do Perpétuo Socorro é representada apenas em quadro, onde se the vê rosto, parte do torso e o menino Jesus. "A imagem tradicional, representada apenas até a cintura, foi aqui completada de tal modo que a figura inteira aparece sentada num trono / altura da figura sentada é de 4 metros)" (Samson Flexor, "A Decoração da lgreja Matriz do Jardim Paulistano em São Paulo folheto editado pela igreja por ocasião da inauguração dos afrescos. São Paulo, 13 de Setembro de 1964: dia da entrega e da inauguração oficial da pintura da lgreja de Nossa Senhora do Perpétuo Socorro do Jardim Paulistanoem São Paulo"I. Não por acaso, o pintor utiliza o termo Abside: segundo uma das acepções, rata-se do nicho semicircular e abobadado, nas basílicas romanas, onde se achava o assento do juiz.

6 Samson Flexor, "A Decoração da Igreja Matriz do Jardim Paulistano em São Paulo", op.

7 Leyla Perrone-Moisés, "Meu Mestre Flexor", in catálogo da exposição Samson Flexor - Modulacões São Paulo Instituto Moreira Salles, s/d pp. 37-8. 
reto, unidas a uma cor pura, capaz de impor sua força cromática sem trair as leis frontais do plano. Logo, porém, as oblíquas e as diagonais definem os desejos cinéticos de Flexor, o apelo dinâmico de um mundo que não pode se contentar em permanecer ancorado, e que, ao contrário, obedece, com ou sem razão, às solicitações do movimento perpétuo"8.

Para uma breve observação desses movimentos a partir dos quais se erigem tanto as figuras como a maneira como elas se inter-relacionam, permito-me novo recorte do friso esquerdo. Limito-me às penúltimas - para quem entra na igreja - figuras do cortejo, que representam algumas das atividades artísticas e intelectuais e o clero, num total de seis delas: o pintor, um homem de vestes negras, de um lado, e três padres da Ordem dos Redentoristas, unidos todos num só bloco pelos braços abertos de um grande anjo, central. Destas, a do homem de negro merece alguma explicação: ele segura um rolo de papel (vegetal?) e tem, a pouca distância de si, régua $T$, esquadro e outro rolo de papel, além da maquete da igreja. Detrás dele, numa mesa, pousa outro rolo, semi-aberto, do mesmo papel. Trata-se de um arquiteto.
Através do jogoenunciação-enunciado, estabelecido pelo retratare pelo retrato, pelo movimento das figuras em busca da Senhora do Perpétuo Socorro, mas, principalmente, pelas linhas diagonais que sustentam não apenas toda a cena em questão como também todas as pinturas desse enorme conjunto, Flexor deixa pulsar outra história. Como num conto, caminham, paralelas, duas narrativas, uma evidente - a "Humanidade Sofredora à Procura de Auxílio” - e outra subterrânea que, como ensina a crítica literária, emerge em pontos isolados, até que deixe de ser "silenciosa e secreta", e transmuta-se numa "revelação final"'.

Pois esse pequeno conjunto, atrevo-me a afirmar, narra, através de sua composição, a história da própria igreja e de seus afrescos. A frase de Foucault, ainda a respeito de Las Meninas, vem corroborar minhas especulações:

"[...] por mais que se diga o que se vê, o que se vê não se aloja jamais no que se diz, e por mais que se faça ver o que se está dizendo por imagens, metáforas, comparações, o lugar onde estas resplandecem não é aquele que os olhos descortinam, mas aquele que as sucessões da sintaxe definem" (grifo meu) ${ }^{10}$.
8 René Deroudille, "Itineraire de Samson Flexor au Musée Rath" in Le Dauphiné Liberé apud Denise Mattar, "Samson Flexor - Modulações", in catálogo da exposição Samson Flexo - Modulações, op. cit., p. 17

9 Refiro-me ao ensaio de Ricardo Piglia, "Borges, el Arte de Narrar" in Cuadernos de Re cienvenido, n. 12, São Paulo, Programade Pós-graduação de Língua Espanhola e Literaturas Espanhola e Hispano-amer cana da USP, 1999. Diz ainda o ensaísta: "Não é um enigma, é uma figura que se oculta. [...] Concluir um relato é descobrir o ponto de cruzamento que permite entrar na outra trama.

10 Michel Foucault, "As Meninas", op. cit., p. 25

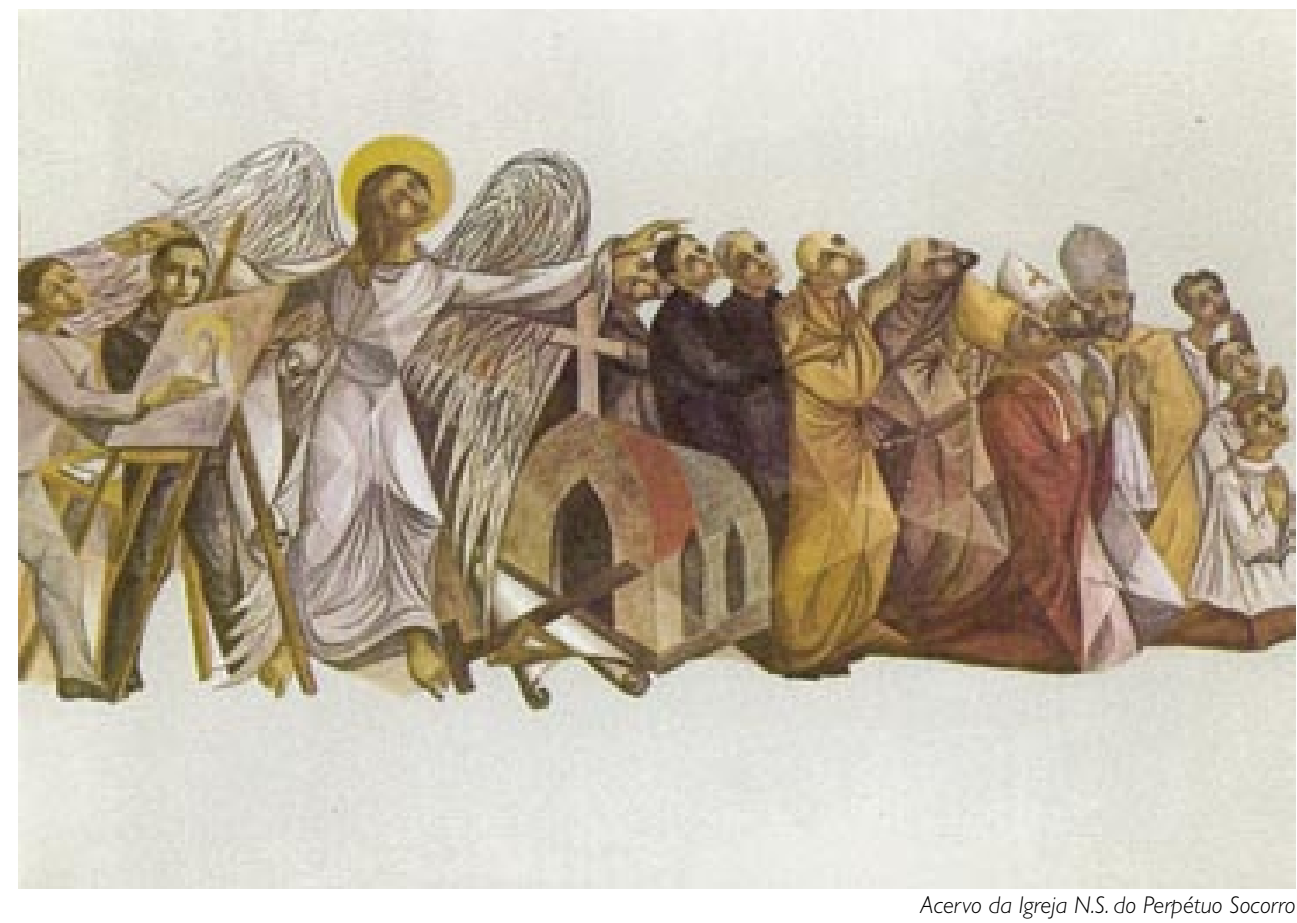


Todas as figuras que compõem o cortejo dos padecentes, segundo Flexor, acompanham o mesmo "jogo rítmico de diagonais" que orienta o movimento dos personagens, dirigindo-os na direção do "Quadro da Abside", como vimos. Isso significa que todos os personagens seguem na mesma direção, ou seja, para a representação de Nossa Senhora do Perpétuo Socorro. Para onde, supõe-se, deveriam mirar.

Nem todos, porém.

Desse grupo observado, nem o pintor nem o arquiteto miram na direção da santa. O pintor reproduz, no tempo ali suspenso, a imagem do anjo que lhe está a pequena distância. Uma linha diagonal transpassa o centro do rosto do pintor, capta seu olhar mas, na realidade, cruza o retrato, exatamente onde ele pousa o crayon. A linha, que extrapola o conjunto das imagens - como uma pluma desgarrada da asa do anjo, destacada no fundo branco da parede -, segue, da pintura do anjo, até formar um ângulo reto com outra diagonal, que será uma das constituintes do corpo do anjo partícipe do cortejo. A indicação, portanto, sugerida pelas diagonais entrecruzadas é que o olhar do pintor não vai em direção a Nossa Senhora, mas para o retrato em progresso ${ }^{11}$. Onde se vê, na verdade, um espelhamento do anjo maior, cujo efeito é propiciado pela sombra invertida dos cabelos de ambos, o anjo retratado na tela e o anjo do cortejo. Noentanto, esse espelhamento não se limita a um efeito ótico. A multiplicação do anjo confere ao que ora é retratado a condição de um retrato de segundo grau, uma vez que reproduz imagem já retratada ${ }^{12}$. Ou, se quisermos um termo mais barroquizante, cria-se aí o efeito de uma sobrenatureza ${ }^{13}$.

Diferentemente do quadro de Velásquez, em que o próprio pintor devora, com seu olhar, a nós outros, que o observamos, no cortejo de Flexor essa apropriação se faz de modo oblíquo, tão oblíquo quanto as linhas diagonais que perpassam as figuras, ajudando a erigi-las. Pois é o olhar de outro que faz as vezes do olhar do pintor, se nos ativermos à norma ditada pelo espanhol: o olhar do arquiteto nos fita, diretamente, sem subterfúgios, a nós, os demais, fiéis ou infiéis que, com isso, somos arrebatados para a cena.

As tonalidades aí empregadas criam um bloco menor, dentro desse de que me ocupo. Pintor, anjo e retrato compartilham exatamente o mesmo tom de verde: pintor e anjo vestem-se da cor, com a diferença de que o anjo apresenta maior luminosidade, graças às nuanças mais claras conseguidas com as dobras do tecido; o retrato soma ao verde o amarelo do halo em torno da cabeça e uma quase sangüínea que marca as plumas das asas, aqui dissolvida nas vestes e mais densa no fundo do quadro. Estabelece-se então, a partir desse cromatismo, uma operação de fundo e forma em que cabe o papel de fundo ao arquiteto, de vestes negras e consideravelmente encoberto pelo quadro e o cavalete-destacado, portanto, do pequeno grupo pelo duplo aspecto do negativo, fotográfico e espacial. Cria-se, portanto, um paradoxo: o dono do olhar mais inquietante, que "nos atinge infalivelmente e nos liga à representação do quadro" - como era o caso de Velásquez, então figura principal -, é, deliberadamente, deixado para ocupar uma posição túrbida: sombria e perturbadora. $\mathrm{E}$, bem mirado, percebe-se o arquiteto soberano em seu ambiente de trabalho - composto de mesa, régua, esquadro e alguns rolos de papel vegetal, que, com suas feições de velhos pergaminhos, brindam uma leveza de movimentos à cena - tendo como convidado de honra o pintor.

E a linha que incorpora o olhar do pintor, atravessa o retrato sendo pintado, junta-se em noventa graus a outra que constrói o torso do grande anjo continua, formando-lhe a dobra do joelho, até terminar ao rés-do-chão da fachada da pequena igreja, praticamente materializada em seus alicerces. Ela é devidamente cortada, nesse trecho, em sua porção central, pela régua $\mathrm{T}$ do arquiteto, de modo a compor, no mesmo tom de marrom, uma cruz, novo efeito de espelhamento com a cruz que se eleva da pequena igreja. O fim dessa extensa e rica diagonal forma o ângulo, em perspectiva, do canto da igreja, no qual se enrola o papel vegetal que, por certo, contém o projeto da edificação. Eoutra diagonal, mais sutil, pode

\footnotetext{
11 Em dois outros auto-retratos Flexor fita seu observador. Em Auto-retrato aos 15 Anos (1922) o rapaz nos olha diretamente. No Auto-retrato (1926) o olhar embora nos fite, já ganha ares oblíquos. Em nenhum deles, porém, o pintor faz qualquer referência à sua atividade.

12 A propósito, uma das acepções do verbo retrataré "reproduzira imagem de; espelhar, refletir".

13 Tomo o termo de Lezama Lima para quem "a penetração da imagem na natureza engendra a sobrenatureza. [...] Frente ao pessimismo da natureza perdida, a invencivel alegria no homem da imagem reconstruída" ["Auto-Retrato Poético", in Fugados, tradução de Josely Vianna Baptista, São Paulo, lluminuras, 1993, p. 84).
} 
ser percebida a partir dos olhos do arquiteto, que nos fita diretamente; passa por trás do retrato, cruza o corpo do anjo próximo de sua cintura, cruza sua asa direita e termina exatamente na linha do telhado da igreja. Com isso, a pequena edificação fica confinada entre duas linhas: a do olhar efetivo do pintor e a que se forma a partir dos olhos do arquiteto. São elas que erigem as dimensões e as proporções, bem como a perspectiva, da igreja ainda em seu estado primeiro, de projeto em volume, a maquete.

Desse bloco de seis figuras, a do pintor e a do arquiteto se completam, sem sequer mirar-se. E é do olhar de ambos que se demarca a edificação do templo. Tanto a retratada - representação em terceiro grau, já que traz de volta à bidimensionalidade um volume, a maquete, cuja função é erigir em pequena escala os planos traçados no papel - como a que os abriga, a igreja Nossa Senhora do Perpétuo Socorro do Jardim Paulistano.

Isso porque, em que pese a importância dos padres para a materialização dos afrescos, foram aqueles dois homens, unidos pela admiração recíproca, que os conceberam. O arquiteto, por alterar o projeto original da igreja, criando espaços enormes, janelas altíssimas, exatamente para encaixar o trabalho de Flexor. E por insistir com o pároco, o padre Alexandre Morais-oterceiro padre retratado, de cabelos brancos -, a favor do nome do artista, contrariando com vigor sua escolha inicial por Antonio Paim Vieira, que assina os afrescos da igreja Nossa Senhora do Brasil. Apresentou padre e pintor, que desenvolveu umextenso projeto, baseadoem profundas reflexões teológicas. Padre Morais, conhecido por suas inseguranças, acabou aprovando o nome e o audaz projeto de Samson Flexor. E justamente a completude dos dois companheiros se concretiza na maquete da igreja, cuja perspectiva tem, em suas linhas de fuga, as linhas que se originam no olhar do pintor e nos olhos do arquiteto.

$\mathrm{O}$ arquiteto Verona, que assina as modificações do projeto inicial da igreja, concebido por Benedito Calix to de Jesus, conheceu Flexor numa exposição que o artista organizou na própria casa, em fins dos anos 1940.
O pintor estava recém-instalado no Brasil e Verona impressionou-se com suas telas de motivos religiosos: comprou, ali, Acusação de Jesus. Começava uma amizade pautada pelo trabalho complementar. $\mathrm{O}$ arquiteto solicitou a Flexor a realização de afrescos em várias residências que projetou ${ }^{14}$, bem como na sede do Club Athlético Paulistano, anos antes da grande composição da Perpétuo Socorro.

Mas Verona é, nessa época, responsável pela apassivação do verbo retratar: Flexor foi, algumas vezes, retratado pelo arquiteto, que também operava câmeras fotográficas e, principalmente, cinematográficas. Talvez a primeira tenha sido com sua câmera fotográfica, em registro do pintor em ação. Mas sem dúvida as mais interessantes são as tomadas feitas do ator Samson Flexor, em dois de seus filmes. Ao Norte do Lassigny ${ }^{15}$ traz Flexor no papel do médico de campanha, narrador da história passada na Primeira Guerra Mundial. Em Tédio ${ }^{16}$, Flexor representa a si mesmo, em pleno exercício da pintura e da reflexão filosófica, no próprio ateliê, na Rua Gaspar Lourenço. Curiosamente, a tomada em que o personagem principal olha pela janela do estúdio e vê crianças brincando numa praça foi tirada do coro da mesma igreja Nossa Senhora do Perpétuo Socorro, sem que o espectador suspeite do estratagema do diretor. Fecha-se, portanto, um círculo estribado na conjugação do mesmo verbo, por dois sujeitos que se alternam na função de retratista/retratado.

Mas ao retratar, como se viu, o retratista - seja ele pintor, fotógrafo ou diretor cinematográfico - faz de seu modelo um ator. Cria-lhe um ambiente, às vezes conferelhe nova persona. Nesse sentido, retratar aproxima-se de um de seus sinônimos, representar, cujo significado aponta para as artes cênicas.

No caso dos afrescos da igreja, Flexor confere aos paroquianos que lhe eram mais próximos a oportunidade de representar um papel. Os retratos do próprio pintor, do arquiteto e do padre Morais não são, portanto, casos isolados. Fiel à tradição medieval de fazer conviver no mesmo suporte figuras 
religiosas e membros das famílias que, em geral, encomendavam os quadros, Flexor retrata ali membros da comunidade. São os elementos da "humanidade sofredora em busca de auxílio", que ele mesmo denomina personagens. Por exemplo, a guerra recebia o rosto de Clóvis Garcia - então vizinho da igreja-que lutou na Itália, como pracinha ${ }^{17}$. Mas houve pelo menos um caso em que ele levou ao pé da letra a acepção cênica da representação: Flexor retratou outro vizinho - desembargador -, que sonhara ser cientista, em pleno gozo de seu desejo. Ele está entre tubos de ensaio e pipetas, transformado no tal "cientista cristão êmulo de Pasteur”, conforme palavras do pintor.

Mas o próprio ato de pintar era, em si mesmo, um ato cênico. Flexor empoleiravase em andaimes de tubos de aço, a dez metros de altura, o que já despertava a curiosidade e a atenção, bem como a apreensão de muitos. Desviava a atenção, atraía o olhar do fiel em busca de lenimento. Deslocava, portanto, o centro - que, canonicamente, é tomado pelo altar-mor - para si. Passava os dias lá em cima, auxiliado por um pedreiro, que lhe preparava a superfície da parede, onde, em pouco tempo - enquanto o reboco ainda estivesse fresco -, ele tinha que decalcar, a carvão, os contornos das figuras, matrizes desenhadas em papel vegetal e depois perfuradas. Só então entrava com as cores, que davam vida às figuras. Algumas senhoras mais pias reclamavam aos padres o fato de o pintor fumar cachimbo dentro da Casa do Senhor. Disciplinado, Flexor fazia suas pausas, que aproveitava para um café regado a boa prosa nas casas vizinhas.

O grande golpe de cena de Flexor foi um ataque de angina, no alto do andaime, que o afastou do trabalho por meses. Mas a assistência foi-lhe fiel, de 1958 a 1964.

\section{SER OU NÃO SER RETRATADO}

À medida que as figuras iam sendo expostas, que os personagens assumiam seus papéis, criou-se, pelo menos entre as crianças - mais explícitas em suas inquietações-, uma

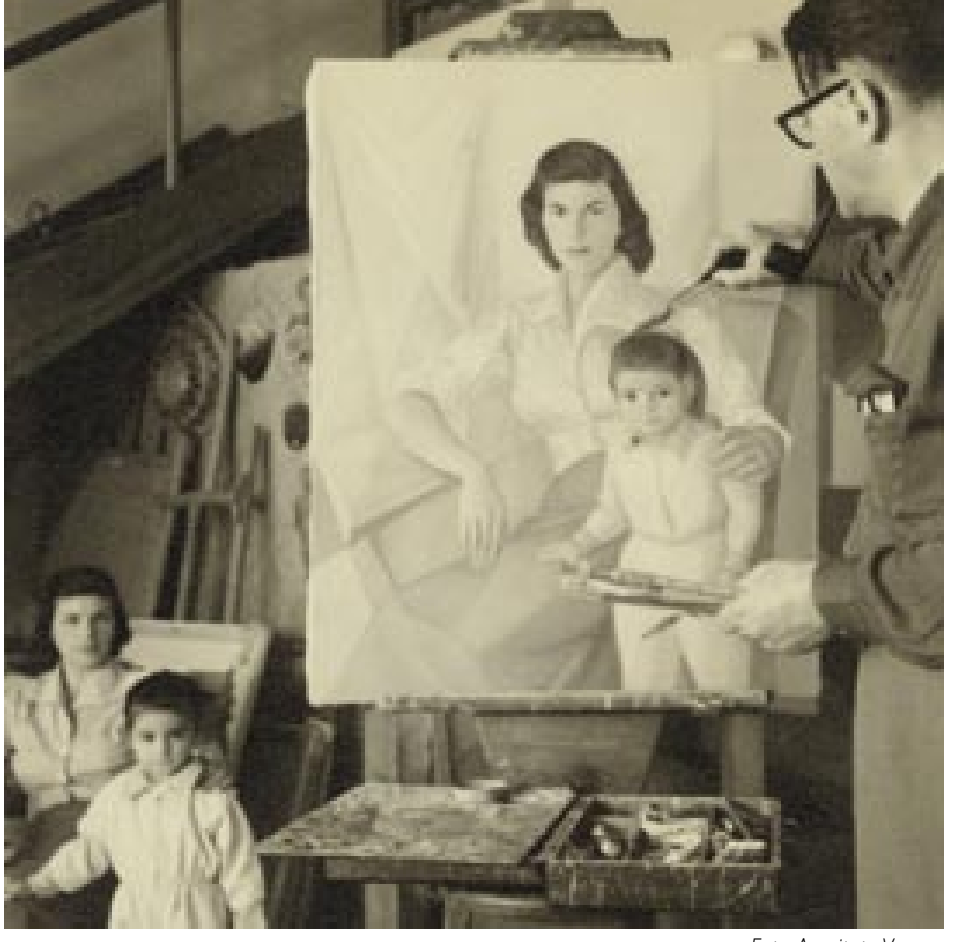

Foto: Arquiteto Verona

hierarquia. Todas desejavam reconhecer-se, ou aos seus, naquele friso esquerdo (o direito não contava, porque sabiam que ali só havia santos). Por anos, durante a obrigatoriedade do sacrifício da missa, essas crianças brincavam o jogo das identificações das figuras, que iam ganhando cores, feições - identidades - a cada semana. Mas apontar, além de feio, era pecado. $\mathrm{O}$ jeito era ir descrevendo cada um dos personagens e ir nomeando um a um. Como Pelé, dona Margot, esposa de Flexor, Édouard, seu cunhado, padre Morais, Verona, Clóvis Garcia, dr. Fairbanks. Noúltimodegrau da brincadeira, bastava identificar, fosse quem fosse. Isso significava pertencer. Em última análise, todos queriam ser parte, direta ou indireta, daqueles enormes frisos, da comunidade, da paróquia, da humanidade em busca de alívio.

Mas o melhor era identificar-se.

Identificar-se transformou a brincadeira em contenda: apenas quatro crianças - uma das quais no caixão-estão ali representadas. As três que interessavam prendem-se a uma única mãe. Triunfariam, então, três irmãos. Mas Flexor concede esses papéis à esposa e à filha, única, do arquiteto. Duas figuras que ele já havia retratado anos antes, enquanto eram, ele próprio e as modelos, retratados pelas lentes da câmera fotográfica do mesmo arquiteto $^{18}$. Nem sempre o fato é soberano, e algumas crianças criavam as próprias versões, encontrando ali quem desejassem. Não sei se ainda crêem em suas fantasias.
17 Clóvis Garcia é advogado, cenógrafo, crítico teatral, além de professor emérito da Escola de Comunicações e Artes IECA USP), onde atua na disciplina de Artes Cênicas.

18 É extensa a lista de retratados por Flexor. No entanto, devo destacar que, mesmo nesse tipo de obra realizada por encomenda, o artista foi sempre fiel a seus princípios: "Para nós, artistas, liberdade é o direito que nos dão de escolher nossa própria prisão, isto é, o direito que nos dão de escolher nossa própria disciplina. No meu ou arte dirigida é um problema condicionado pela sociedade em que vive o pintor. Quando este faz seus trabalhos baseado em pesquisas individuais, 0 menor dirigismo significaria a inutilidade dessas pesquisas. Entretanto, quando o artista aceita uma encomenda, seja ela uma tela ou um mural, deve ter a capacidade suficiente para fazer obra de arte dentro das condições do que the é pedido". Samson Flexor, "Um Debate Oportuno sobre Artes Plásticas", entrevista concedida ao jornal Folha da Manhã São Paulo, 17/11/1948 apud Denise Mattar, "Samson Flexor-Modulações", op. cit. p. 17. modo de entender, arte livre 


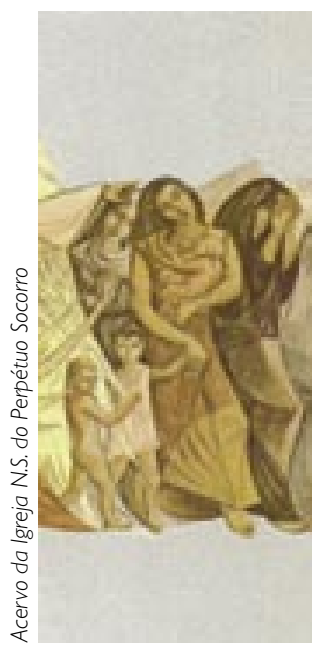

Entre a conclusão das pinturas em toda a extensão da nave da igreja e o final propriamente dos trabalhos houve um interregno. Flexor aproveitou-o para viajar, fazer exposições na Europa, viver fora. A volta foi marcada por uma série de negociações com os padres, até que, finalmente, ele retomou a atividade. Esse último trecho da pintura foi o que menos, digamos, frisson provocou nos fiéis. Trata-se do batistério, que se localiza logo na entrada da igreja, à esquerda, e toma toda a parede, de dimensões próximas às caseiras. Não havia, portanto, altitudes, tubulações, riscos, perigos. Muito menos personagens da comunidade, apenas Cristo e São João Batista. As crianças já estavam crescidas, não se impressionavam tanto com um artista que lhes era familiar havia anos. Nem mesmo o confundiam com outro, que pintou outra igreja, longe na geografia e na história. A filha do arquiteto, nos primeiros tempos em que assistia a Flexor em sua atividade, encarapitado em andaimes próximos do teto da igreja, chegou a ver no amigo da família, de fala macia afrancesada, uma alteridade de Michelangelo, cuja história o pai lhe narrava.

Mas os tempos agora eram outros, e o trabalho, finalmente, chegava ao fim.

Não para Flexor nem para essa menina, filha do arquiteto.

Flexor ligou ao amigo. Queria que a menininha - assim era chamada em seu ateliê - passasse ali todas as tardes de uma semana, vestida e penteada sempre do mesmo modo. Pediu-lhe sigilo. Ela posou, sozinha, sem as lentes do pai. Em compensação, os chocolates de dona Margot estavam sempre presentes, ciosamente oferecidos por ela, na enorme caixa com divisórias marrons.

No último dia, foram juntos, pintor e modelo, para casa, Flexor carregando uma enorme aquarela, o retrato da filha do velho amigo, com uma dedicatória:

"Para meus amigos Henrique e Zelinda esta lembrancinha da Terezinhae doFlexor. São Paulo 1964."

Terminava ali, finalmente, o longo período da elaboração e execução dos afrescos da Perpétuo Socorro. Fechava-se a cena com uma nova representação.

Pano rápido.

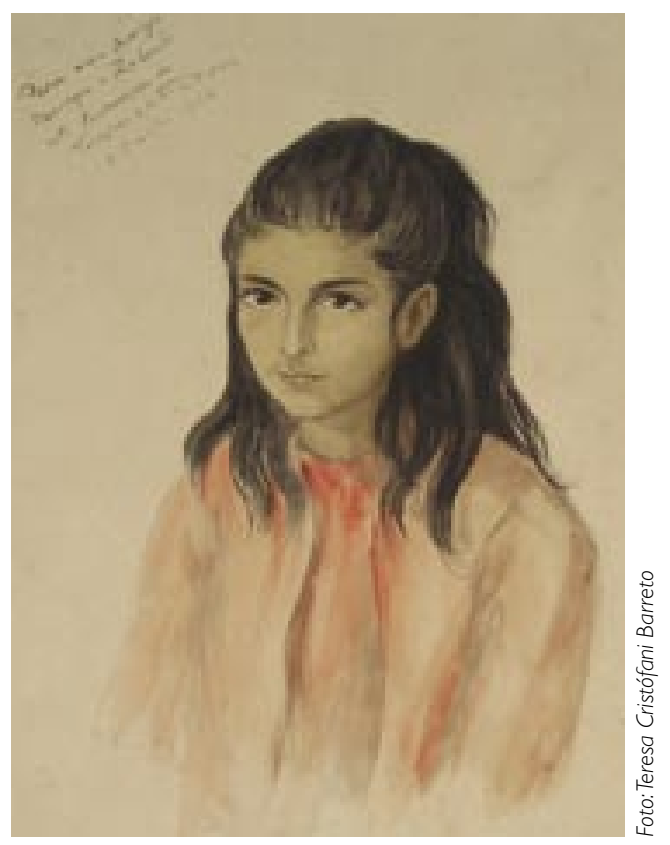

